\title{
A comparative antimicrobial study on Cordia macleodii. hook leaf water extract and its ghrita base formulation
}

\author{
Research Article
}

\author{
Sharma Ashish ${ }^{1}$, Acharya RN $^{2 *}$, Shukla VJ ${ }^{3}$, Gupta S.K ${ }^{4}$ \\ 1. PG Scholar, 2. Associate Professor, Dept. of Dravyaguna, \\ 3. Head, Pharmaceutical Chemistry Laboratory, \\ 4. Associate Professor, Dept. of Shalyatantra, \\ IPGT \&RA, Gujarat Ayurved University, Jamnagar.
}

\begin{abstract}
Cordia macleodii Hook. of family Boraginaceae (Ehretiaceae) is reported for its ethnomedicinal use as a wound healing drug. An attempt has been made to evaluate the antibacterial activity of its leave along with its ghrita base preparation against medically important human pathogenic bacteria (two gram positive- S. aureus, S. pyogenes, two gram negative- E. coli, $P$. aeruginosa) and fungal strains- A.niger, C. albicans, at different concentrations $(5,25,50,100,250 \mu \mathrm{g} / \mathrm{ml})$, using agar disc diffusion method. Zone of inhibition of these samples was compared with that of different standards (Ampicilline, Ciprofloxacin, Norfloxacin and Chloramphenicol for antibacterial activity and Nystain and Greseofulvin for antifungal activity). Only ghrita showed more effective result, at different concentration, in comparison to leave water extract and ghrita base formulation.
\end{abstract}

Key words: Antimicrobial, Boraginaceae, Cordia macleodii, Ghrita, Ghee, Leaf

\section{Introduction:}

Ayurveda recommends large number of medicinal plants for the management of fresh as well as chronic wounds. (1) These medicinal plants have a wide variety of chemical constituents and some of them have the ability to inhibit the growth of micro organisms.(2) Cordia macleodii Hook, is reported for its ethno-medicinal use as a wound healing drug.(3) The antimicrobial and wound healing action of water extract of this plant have been reported. (4) For the management of

*Corresponding Author:

Rabinarayan Acharya

Associate Professor

Department of Dravyaguna,

IPGT\&RA,

Gujarat Ayurved University,

Jamnagar.

Contact No. 09924585855

Email - drrnacharya@gmail.com wound, Ayurveda advocates to use different doses of the drug like Taila (oil), Ghrita (ghee), Siktha (wax) through external application(5). Ghrita alone has been also reported for it's wound healing properties.(6) In the present study, an attempt has been made to compare the antimicrobial property of water extract of C. macleodii leaf with that of Ghrita and Ghrita base preparation from its leaves.

\section{Materials and Methods \\ Collection of drug:}

The drug (Fresh leaf of $C$. macleodii) for the present study was collected by the scholar from its reported habitat (Hoshangabad District of Madhya Pradesh) after proper identification. Cow's ghrita was procured from Khadi Gramodyoga Bhandara, Jamnagar and used for preparation of ghrita and alone in experimental study being leveled as SG. 


\section{Preperation of formulation:-}

The test drug i.e. Ghrita base formulation of Cordia macleodii leaves was prepared by following the standard procedure of Sneha Kalpana described in Sharangdhara Samhita (7) and the prepared drug was leveled as CMG.

\section{Preparation of Leaf extract:-}

Water extract from the leaves was obtained following the procedures mentioned in Ayurvedic Pharmacopoeia of India (8) and the leveled as CML.

\section{Selection of microorganisms:}

\section{Staphylococcus aureus (MTCC} 96), Streptococcus pyogenes (MTCC 442), Escherichia coli (MTCC 443), Pseudomonas aeruginosa (MTCC 424) \& fungal strains Aspergillus niger (MTCC 282), Candida albicians (MTCC 227) were chosen based on their clinical and pharmacological importance. The bacterial strains, obtained from Institute of Microbial Technology, Chandigarh, were used for evaluating antimicrobial activity. The bacterial and fungal stock cultures were incubated for $24 \mathrm{~h}$ at $37^{\circ} \mathrm{C}$ on Nutrient Agar and Potato Dextrose Agar medium (Microcare laboratory, Surat, Gujarat, India) respectively following refrigeration storage at $4^{\circ} \mathrm{C}$. The bacterial strains were grown in Mueller-Hinton agar (MHA) plates at $37^{\circ} \mathrm{C}$ ( The bacteria were grown in the nutrient broth at $37^{\circ} \mathrm{C}$ and maintained on nutrient agar slants at $4^{\circ} \mathrm{C}$ ) whereas the yeasts and molds were grown in Sabouraud dextrose agar (SDA) and potato dextrose agar (PDA) media, respectively, at $28^{\circ} \mathrm{C}$. The stock cultures were maintained at $4^{\circ} \mathrm{C} .(\mathbf{9 , 1 0 , 1 1 , 1 2 )}$

\section{Antimicrobial activity Determination of zone of inhibition( zoi) method}

In vitro antimicrobial activity testing was carried out by using Agar cup method. Each purified extracts were dissolved in Dimethyl Sulfoxide (DMSO), sterilized by filtration using sintered glass filter and stored at $4^{\circ} \mathrm{C}$. For the determination of ZOI, pure Gram positive, Gram negative and fungal strains were taken as a standard antibiotic for comparison of the results. All the extracts were screened for their antibacterial and antifungal activities against the $E$. coli, $P$. aeruginosa, $S$. aureus, $S$. pyogenes and the fungi C.albicans and A. niger. The sets of five dilutions $(5,25,50,100$ and 250 $\mu \mathrm{g} / \mathrm{ml}$ ) of Cordia macleodii leaf extract,Cordia macleodii ghrita and Shuddha ghrita and standard drugs were prepared in double distilled water using nutrient agar tubes. Muller Hinton sterile agar plates were seeded with indicator bacterial strains $(108 \mathrm{cfu})$ and allowed to stay at $37^{\circ} \mathrm{C}$ for $3 \mathrm{~h}$. Control experiments were carried out under similar condition by using Ampicillin, Chloramphenicol, Ciprofloxacin and Norfloxacin for antibacterial activity and Nystatin and Greseofulvin for antifungal activity as standard drugs. The zones of growth inhibition around the disks were measured after 18 to $24 \mathrm{~h}$ of in incubation at $37^{\circ} \mathrm{C}$ for bacteria and 48 to $96 \mathrm{~h}$ for fungi at $28^{\circ} \mathrm{C}$, respectively. The sensitivity of the microorganism species to the plant extracts were determined by measuring the sizes of inhibitory zones (including the diameter of disk) on the agar surface around the disks, and values $<8 \mathrm{~mm}$ were considered as not active against microorganisms.

\section{Results and discussion:- Microbial load}

C. macleodii leaf water extract(CML), Shuddha Ghruta( SG) and C. macleodii Ghruta(CMG) were studied for microbial load (Total microbial count, total bacterial count and total fungal count) and was found within prescribed limit. All the tested pathogens were absent in all the three samples before their antimicrobial evaluation (Table -1). 
Table 1: $\quad$ Microbial load reported in $C$ macleodii Leaf Ghrita, $C$ macleodii Leaf water extract and Shuddha Ghrita

\begin{tabular}{|c|c|c|c|c|c|}
\hline S.No. & $\begin{array}{c}\text { Test } \\
\text { parameter }\end{array}$ & SG & CML & CMG & $\begin{array}{l}\text { Prescribed } \\
\text { Limit }\end{array}$ \\
\hline \multirow[t]{3}{*}{1.} & $\begin{array}{c}\text { Total } \\
\text { microbial } \\
\text { count }\end{array}$ & $\begin{array}{l}20 \text { CFU per } \\
\text { gm }\end{array}$ & $\begin{array}{l}40 \mathrm{CFU} \text { per } \\
\text { gm }\end{array}$ & $\begin{array}{c}30 \mathrm{CFU} \text { per } \\
\mathrm{gm}\end{array}$ & \multirow[t]{3}{*}{$\begin{array}{l}100 \mathrm{CFU} \text { per } \\
\mathrm{gm}\end{array}$} \\
\hline & $\begin{array}{c}\text { Total bacterial } \\
\text { count }\end{array}$ & $\begin{array}{l}10 \text { CFU per } \\
\text { gm }\end{array}$ & $\begin{array}{l}30 \text { CFU per } \\
\text { gm }\end{array}$ & $\begin{array}{c}20 \text { CFU per } \\
\text { gm }\end{array}$ & \\
\hline & $\begin{array}{c}\text { Total fungal } \\
\text { count }\end{array}$ & $\begin{array}{l}10 \text { CFU per } \\
\text { gm }\end{array}$ & $\begin{array}{l}10 \text { CFU per } \\
\text { gm }\end{array}$ & $\begin{array}{c}10 \text { CFU per } \\
\text { gm }\end{array}$ & \\
\hline \multirow{5}{*}{2.} & Pathogens & & & & \\
\hline & E.Coli & Absent & Absent & Absent & \multirow{4}{*}{$\begin{array}{l}\text { Should be } \\
\text { absent per } \\
10 \mathrm{~g}\end{array}$} \\
\hline & $\begin{array}{l}\text { Salmonella } \\
\text { spp. }\end{array}$ & Absent & Absent & Absent & \\
\hline & $\begin{array}{c}\text { Pseudomonas } \\
\text { aeruginosa }\end{array}$ & Absent & Absent & Absent & \\
\hline & S. aureus & Absent & Absent & Absent & \\
\hline
\end{tabular}

Table No.2 Antibacterial activities (zone of inhibition) of test drugs on gram negative bacteria

\begin{tabular}{|l|l|l|l|l|l|l|l|l|l|l|}
\hline $\begin{array}{l}\text { Coded } \\
\text { test drugs }\end{array}$ & E. coli MTCC 443 & P. aeruginosa MTCC 424 & \\
\hline \multicolumn{10}{|c|}{ Diameter of zone of inhibition in mm } \\
\hline & 5 & 25 & 50 & 100 & 250 & 5 & 25 & 50 & 100 & 250 \\
& $\mu \mathrm{g} / \mathrm{ml}$ & $\mu \mathrm{g} / \mathrm{ml}$ & $\mu \mathrm{g} / \mathrm{ml}$ & $\mu \mathrm{g} / \mathrm{ml}$ & $\mu \mathrm{g} / \mathrm{ml}$ & $\mu \mathrm{g} / \mathrm{ml}$ & $\mu \mathrm{g} / \mathrm{ml}$ & $\mu \mathrm{g} / \mathrm{ml}$ & $\mu \mathrm{g} / \mathrm{ml}$ & $\mu \mathrm{g} / \mathrm{ml}$ \\
\hline CMG & Nil & 15 & 17 & 19 & 20 & Nil & 14 & 16 & 17 & 18 \\
\hline SG & Nil & 16 & 18 & 19 & 21 & Nil & 15 & 17 & 18 & 20 \\
\hline CML & Nil & 14 & 16 & 17 & 19 & Nil & 13 & 19 & 16 & 18 \\
\hline
\end{tabular}

Table No.3 Antibacterial activities (zone of inhibition) of test drugs on gram positive bacteria

\begin{tabular}{|l|l|l|l|l|l|l|l|l|l|l|}
\hline $\begin{array}{l}\text { Coded } \\
\text { test drugs }\end{array}$ & S. aureus & \multicolumn{7}{c|}{ S. pyogenus MTCC 96 442 } \\
\hline \multicolumn{9}{|c|}{ DTCCter of zone of inhibition in mm } \\
\hline & 5 & 25 & 50 & 100 & 250 & 5 & 25 & 50 & 100 & 250 \\
& $\mu \mathrm{g} / \mathrm{ml}$ & $\mu \mathrm{g} / \mathrm{ml}$ & $\mu \mathrm{g} / \mathrm{ml}$ & $\mu \mathrm{g} / \mathrm{ml}$ & $\mu \mathrm{g} / \mathrm{ml}$ & $\mu \mathrm{g} / \mathrm{ml}$ & $\mu \mathrm{g} / \mathrm{ml}$ & $\mu \mathrm{g} / \mathrm{ml}$ & $\mu \mathrm{g} / \mathrm{ml}$ & $\mu \mathrm{g} / \mathrm{ml}$ \\
\hline CMG & Nil & 17 & 18 & 20 & 21 & Nil & 12 & 14 & 17 & 19 \\
\hline SG & Nil & 17 & 18 & 21 & 22 & Nil & 14 & 16 & 17 & 20 \\
\hline CML & Nil & 17 & 18 & 20 & 22 & Nil & 15 & 17 & 19 & 22 \\
\hline
\end{tabular}

Table No.4:-Antibacterial activities ( zone of inhibition) of standard drugs on gram negative bacteria

\begin{tabular}{|l|l|l|l|l|l|l|l|l|l|l|}
\hline $\begin{array}{c}\text { Standard } \\
\text { drugs }\end{array}$ & \multicolumn{1}{c|}{ E. coli MTCC 443 } & \multicolumn{1}{l|}{ P. aeruginosa MTCC 424 } \\
\hline \multicolumn{10}{|c|}{ Diameter of zone of inhibition in mm } \\
\hline & $\begin{array}{l}5 \\
\mu \mathrm{g} / \mathrm{m}\end{array}$ & \begin{tabular}{l}
$\mu \mathrm{g} / \mathrm{m}$ \\
\hline
\end{tabular} & $\begin{array}{l}50 \\
\mu \mathrm{g} / \mathrm{m}\end{array}$ & $\begin{array}{l}100 \\
\mu \mathrm{g} / \mathrm{m}\end{array}$ & $\begin{array}{l}250 \\
\mu \mathrm{g} / \mathrm{m}\end{array}$ & $\begin{array}{l}5 \mathrm{~g} / \mathrm{m} \\
\mu \mathrm{g} / \mathrm{m}\end{array}$ & $\begin{array}{l}50 \\
\mu \mathrm{g} / \mathrm{m}\end{array}$ & $\begin{array}{l}100 \\
\mu \mathrm{g} / \mathrm{m}\end{array}$ & $\begin{array}{l}250 \\
\mu \mathrm{g} / \mathrm{m}\end{array}$ \\
\hline
\end{tabular}


Sharma Ashish et. al., Antimicrobial Evaluation of Cordia macleodii. Hook Leaf Ghrita

\begin{tabular}{|l|l|l|l|l|l|l|l|l|l|l|l|}
\hline & 1 & 1 & 1 & 1 & 1 & 1 & 1 & 1 & 1 & 1 \\
\hline Ampicilline & 14 & 15 & 16 & 19 & 20 & \multicolumn{5}{|l|}{$\mid$} \\
\hline $\begin{array}{l}\text { Chloramphenic } \\
\text { ol }\end{array}$ & 14 & 17 & 23 & 23 & 23 & 14 & 17 & 18 & 19 & 21 \\
\hline Ciprofloxacin & 20 & 23 & 28 & 28 & 28 & 20 & 23 & 24 & 26 & 27 \\
\hline Norfloxacin & 22 & 25 & 26 & 26 & 29 & 18 & 19 & 21 & 23 & 23 \\
\hline
\end{tabular}

Table No.5:-Antibacterial activities ( zone of inhibition) of standard drugs on gram positive bacteria

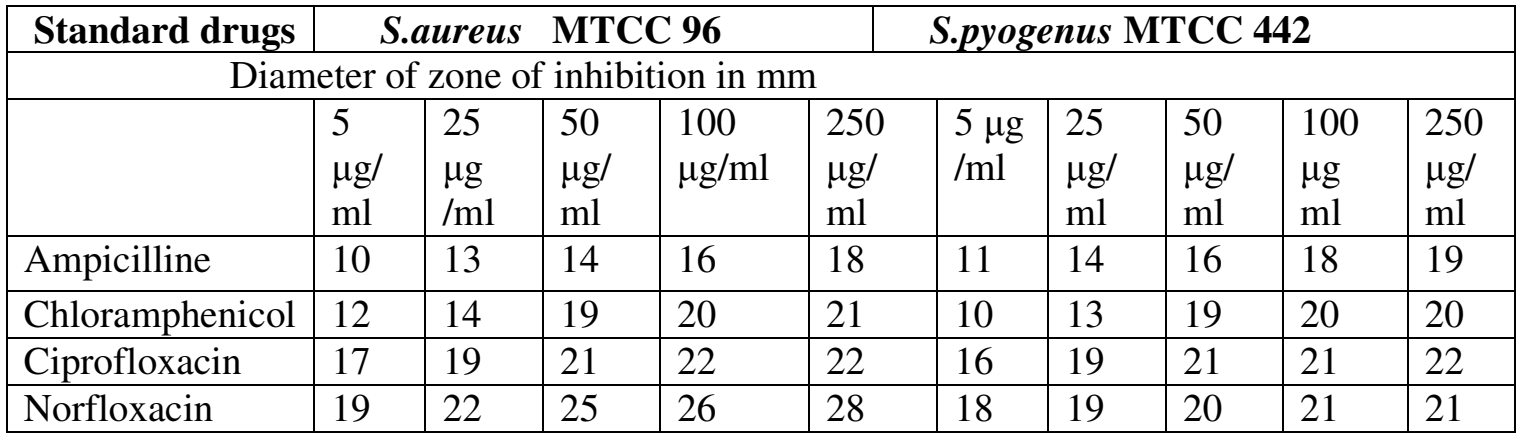

Table No.6: Antifungal activities ( zone of inhibition) of test drugs

\begin{tabular}{|l|l|l|l|l|l|l|l|l|l|l|}
\hline $\begin{array}{c}\text { Coded } \\
\text { test drugs }\end{array}$ & \multicolumn{1}{c|}{ A. niger MTCC 282 } & \multicolumn{7}{c|}{ C. albicans MTCC 227 } \\
\hline \multicolumn{9}{|c|}{ Diameter of zone of inhibition in mm } \\
\hline & 5 & 25 & 50 & 100 & 250 & 5 & 25 & 50 & 100 & 250 \\
& $\mu \mathrm{g} / \mathrm{ml}$ & $\mu \mathrm{g} / \mathrm{ml}$ & $\mu \mathrm{g} / \mathrm{ml}$ & $\mu \mathrm{g} / \mathrm{ml}$ & $\mu \mathrm{g} / \mathrm{ml}$ & $\mu \mathrm{g} / \mathrm{ml}$ & $\mu \mathrm{g} / \mathrm{ml}$ & $\mu \mathrm{g} / \mathrm{ml}$ & $\mu \mathrm{g} / \mathrm{ml}$ & $\mu \mathrm{g} / \mathrm{ml}$ \\
\hline CMG & - & 13 & 15 & 17 & 20 & - & 14 & 16 & 19 & 22 \\
\hline SG & - & 14 & 15 & 18 & 20 & - & 15 & 16 & 18 & 20 \\
\hline CML & - & 13 & 14 & 17 & 19 & - & 15 & 16 & 17 & 21 \\
\hline
\end{tabular}

Table No.7: Antifungal activities ( zone of inhibition) of standard

\begin{tabular}{|c|c|c|c|c|c|c|c|c|c|c|}
\hline \multirow{3}{*}{\begin{tabular}{|l|}
$\begin{array}{l}\text { Standard } \\
\text { drugs }\end{array}$ \\
\end{tabular}} & \multicolumn{5}{|c|}{ A. niger MTCC 282} & \multicolumn{5}{|c|}{ C. albicans MTCC 227} \\
\hline & \multicolumn{10}{|c|}{ Diameter of zone of inhibition in $\mathrm{mm}$} \\
\hline & $\begin{array}{l}5 \\
\mu \mathrm{g} / \mathrm{m} \\
1\end{array}$ & $\begin{array}{l}25 \\
\mu \mathrm{g} / \mathrm{m} \\
1\end{array}$ & $\begin{array}{l}50 \\
\mu \mathrm{g} / \mathrm{m} \\
1\end{array}$ & $\begin{array}{l}100 \\
\mu \mathrm{g} / \mathrm{m} \\
1\end{array}$ & $\begin{array}{l}250 \\
\mu \mathrm{g} / \mathrm{m} \\
1\end{array}$ & $\begin{array}{l}5 \\
\mu \mathrm{g} / \mathrm{m} \\
1\end{array}$ & $\begin{array}{l}25 \\
\mu \mathrm{g} / \mathrm{m} \\
1\end{array}$ & $\begin{array}{l}50 \\
\mu \mathrm{g} / \mathrm{m} \\
1\end{array}$ & $\begin{array}{l}100 \\
\mu \mathrm{g} / \mathrm{m} \\
1\end{array}$ & $\begin{array}{l}250 \\
\mu \mathrm{g} / \mathrm{m} \\
1\end{array}$ \\
\hline $\begin{array}{l}\text { Greseofulvi } \\
n\end{array}$ & 19 & 23 & 25 & 25 & 28 & 18 & 21 & 22 & 22 & 24 \\
\hline Nystatin & 18 & 19 & 24 & 29 & 29 & 18 & 21 & 24 & 25 & 26 \\
\hline
\end{tabular}


Graph No.:1 Antibacterial activity against $E$. coli


Graph No-2 Antibacterial activity against $P$. aeruginosa
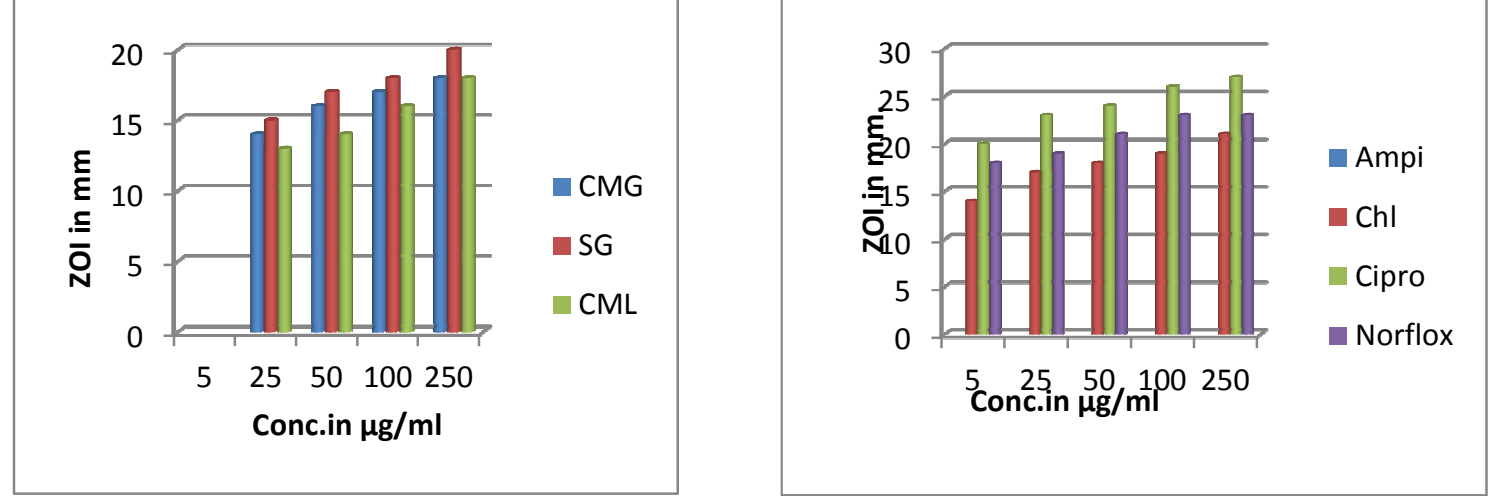

Graph No-3 Antibacterial activity against S.aureus
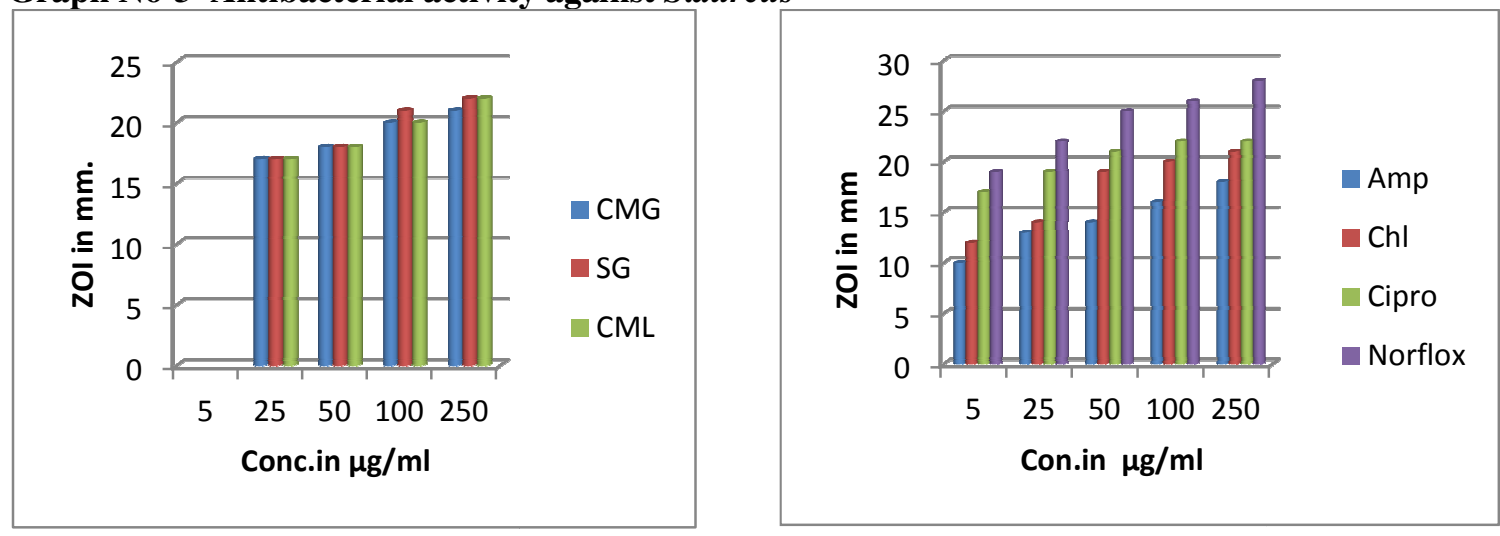
Graph No-4 Antibacterial activity against S.pyogenus
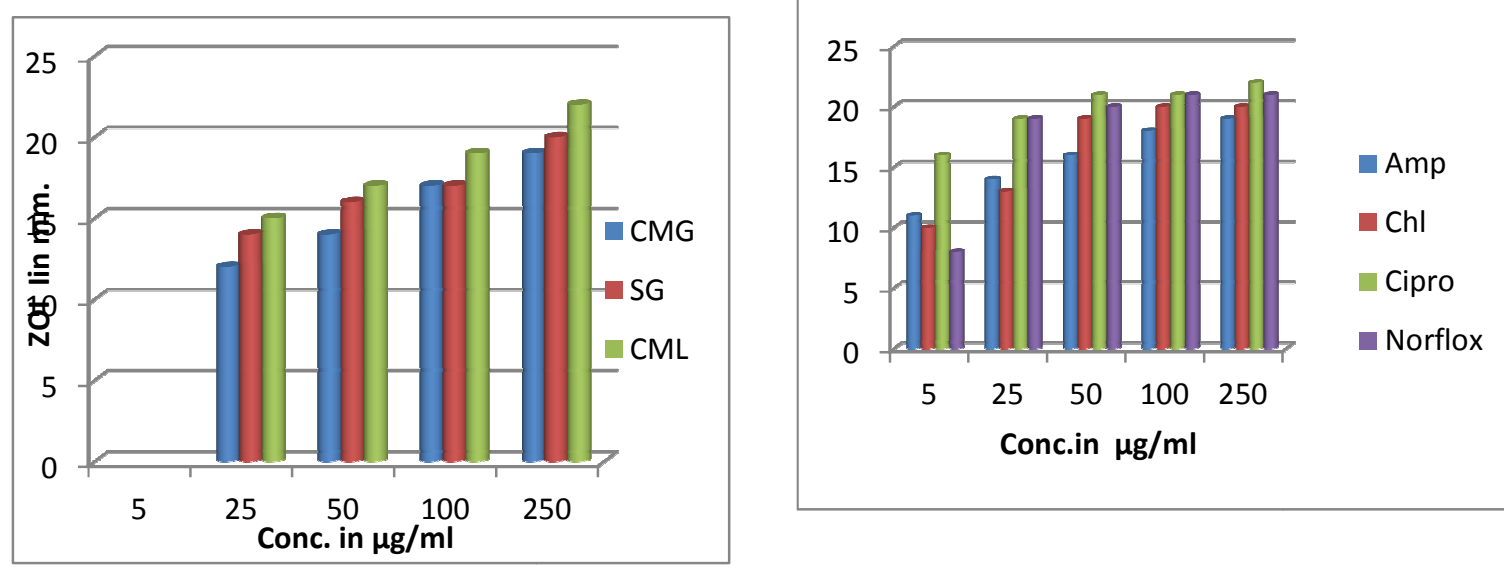

Graph No.5: Antifungal activity against $A$. niger
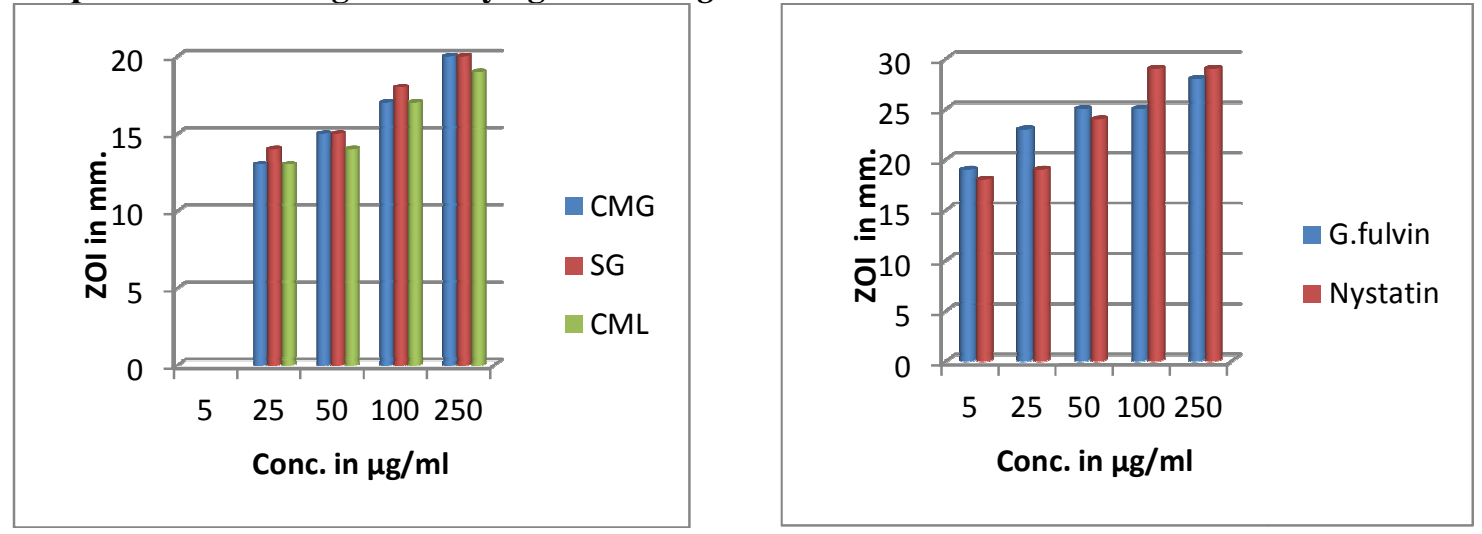

Graph No.6- Antifungal activity against $C$. albicans
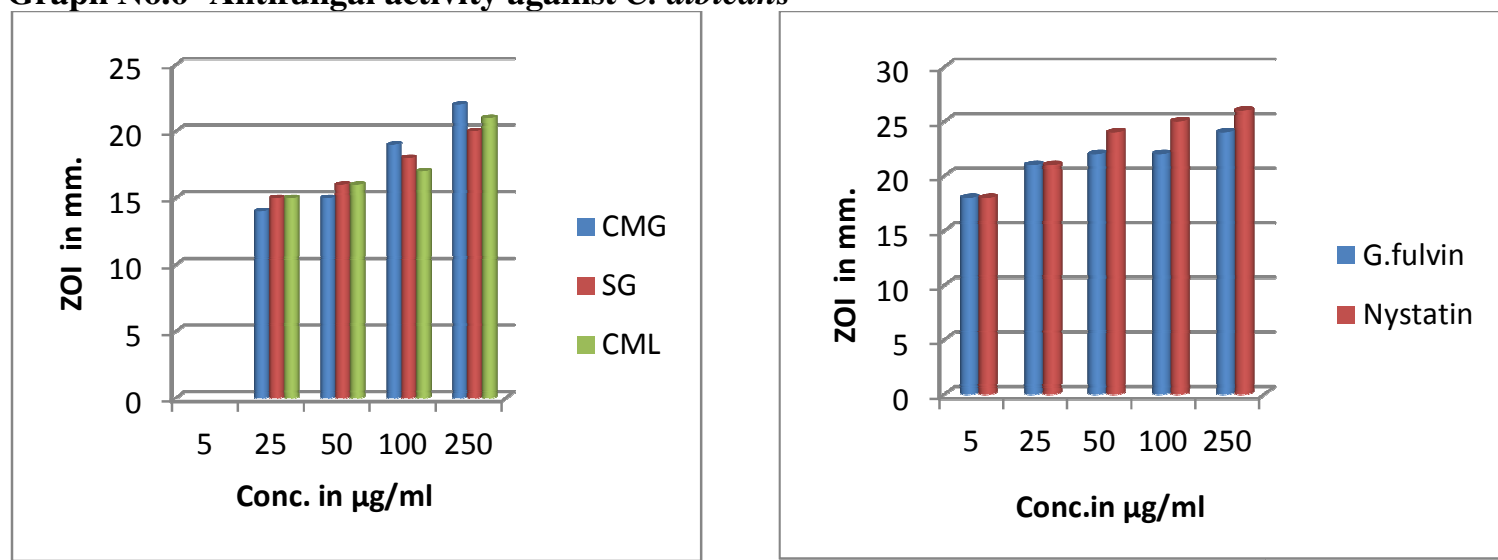
Antibacterial activity of test drugs against $\boldsymbol{E}$. coli.

Test drugs did not affect any of the pathogens at $5 \mu \mathrm{g} / \mathrm{ml}$ concentration where as all the standard drugs affect at all the tested levels of concentrations. At concentration of $25 \mu \mathrm{g} / \mathrm{ml}$ SG showed maximum effect i.e. 16, in standard group Norfloxacin showed maximum.effect 25; at the concentration of $50 \mathrm{SG}$ shows maximum effect,while at concentration of 100 and 250 CMG and SG shows maximum effect respectively.

\section{Antibacterial activity of test drugs against $P$. auregenosa}

Test drug shows no effect against P.aeruginosa at concentration 5 but the standard drugs shows the zone of inhibition on same concentration. At concentration of 25and 50 SG shows relatively more activity and in standard group Ciprofloxacin is more effective.

\section{Antibacterial activity of test drugs against $S$. auresus.}

Test drug shows no effect against S.auresus at concentration 5 but the standard drugs shows its effect .At concentration of 25 and 50 all three test drugs shows similar effect but in standard group Norfloxacin has maximum strength. At concentration of 250 the potency of CMG is equal to Chloremphenical.At this concentration, the potency of $S G$ and $C M L$ is equal to the standard drug Ciprofloxacin.

\section{Antibacterial activity of test drugs against $S$. pyogenus.}

Test drug shows no effect against S.pyogenus at concentration 5 but the standard drugs shows its effect .At concentration of 25 and the zone of inhibition is equal to Ampicilline i.e.14 and concentration of $25,50,100$ and 250
CML showed maximum inhibition than other two.

\section{Antifungal activity of test drugs against} C. albicans and A. niger.

Test drugs did not affect any of the pathogens at $5 \mu \mathrm{g} / \mathrm{ml}$ concentration where as all the standard drugs affect at different levels against A.niger. At concentration of 250 SG and CMG both have equal zone of inhibition but against C.albicans almost similar zone of inhibition was found at different concentration levels.

\section{Conclusion:-}

The three tested drugs (Cordia macleodii ghrita, Shuddha ghrita and Cordia macleodii leaf) showed antibacterial activity against the tested organisms. The effectiveness is more when the concentration is more. Among all the tested drugs Shuddha ghrita showed better result.

\section{Acknowledgement:-}

The authors like to acknowledge The Director, IPGT\&RA, Jamnagar for providing facilities to carry out research work. Author expresses their sincere thanks to Dr. D.P.Rajani, Director, Microcare laboratory Surat, for cooperation and support while doing antimicrobial activity of different samples. Authors also express their sincere thanks to Dr. P. K. Prajapati and Dr. Galib for their valuable support during preparation of formulation and $\mathrm{Mr}$ Pareswar Sahu, Pharmacognosist and Mr. B N Hota, Bargarh, Odisha, for their help during collection and identification of the plant drug.

\section{References:-}

1. Wright, Colin W. and J. David Phillipson. Natural products and Development of selective antiprotozoal 
drugs. Phytotherapy research. Aug.1990; 4 (4); 127-139

2. Ikram $M$ and Inamul Haq. Screening of medicinal plants for antimicrobial activity. Fitoterapia. 1984; 55; 62-64

3. Dubey P.C. Sikarwar, RLS Tiwari Arjun, Ethnobotany of Cordia macleodii, Shodha samagya. 2008; 2: 31-33

4. Bhargav Bhide, R.N.Acharya, BK Ashok, B.Ravishankar, Antimicrobial and wound healing activities of Cordia macleodii Hook.f \&Thoms.leaves. Indian journal of natural products \&Resourses. June 2011; 1(2);198-203

5. Sushrut Samhita of Acharya Sushruta By Dr. Anantrama Sharma. 2008ed. Varanasi; Choukhambha Surbharati Prakashana 2008; 155p.

6. Dinesh Motilal Biyani, Verma P R P, Dorle A K, Boxey V. Wound Healing activity Of Cow ghee: A Veterinary case report. International Journal of Ayurvedic Medicine; 2011; 2 (3); 115-118

7.. Sharngadhara Samhita By Pt. Sharngadhara acharya with the commentaries Adhamalla's Deepika and Kashiram's Gudhartha Deepika. 2000 ed. Varanasi; Krishnadas Academy 2000; 212-215p.

8. Anonymous, Ayurvedic Pharmacopoeia of India. $1^{\text {st }}$ ed. New Delhi; Govt. of India Ministry of Health and Family Welfare, Department of AYUSH, 2008; 2(2); appendix 22(1); 160-161p.

9. Cl Lynne S. Garcia, Henry D. Isenberg. Clinical microbiology procedures handbook. $2^{\text {nd }}$ ed. Washington DC; 2007; 50p

10. N C Desai, P N Shihora, D L Mishra, Synthesis and characterization of new quinazolines as potential antimicrobial agents. Indian journal of chemistry. 2007;46b 550-55p

11. National Committee for Clinical Laboratory Standards. Methods for Dilution, Antimicrobial

Susceptibility Tests for Bacteria that Grow Aerobically Approved Standard.(M7A5), 5th ed.; NCCLS Wayne, PA, 2000

12. Shadomy, S.Albert B. In Manual of Clinical Microbiology. $10^{\text {th }}$ ed. Washington DC ; ASM Press; 1991; 1173p. 